\title{
Assessing the impact of EU rural development programs on tourism
}

\author{
AQ1 Juan Gabriel Tirado Ballesteros ${ }^{\mathrm{a}}$ (D) and María Hernández Hernández ${ }^{\mathrm{b}}$

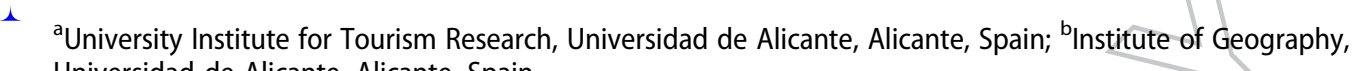

\section{ABSTRACT}

In many areas, rural development programs represent the main driver of tourism. Evaluation is essential to assess the effectiveness and efficiency of the resources allocated. However, although evaluation is mandatory under the European Commission, the methods proposed to date have paid insufficient attention to the impact of tourism. The aim of this paper is to examine the methodological tools used by the European Union to evaluate rural development programs. We conducted an analysis of European Union working documents concerning evaluation, and also performed a literature search in the main scientific databases. A total of 75 documents were studied and categorized into: (a) studies analyzing methodology, (b) descriptive studies and funding analyses, (c) contributions on the evaluation process, and (d) tourism-related studies. Although several methods have been proposed to improve the European Union's evaluation systems, few studies have assessed the impact of tourism generated by rural development programs.

\section{KEYWORDS}

Rural development; LEADER method; evaluation; tourism; EAFRD

\section{Introduction}

European rural development policies emerged in response to the difficulties facing the European agricultural sector in the 1980s. These were the result of productivist-based policies that led to excess agricultural production, obliging the European Union to redirect energies toward controlling price distortion and managing surplus production. Simultaneously, questions began to be raised about the environmental impact of the Common Agricultural Policy development model. In the light of these issues, in 1988 the European Commission published The future of rural society, a document that marked a change in direction for agricultural policies and the inception of a new concept: rural development (European Commission, 1999a). The European Community proposed the introduction of new actions in rural areas that went beyond the simple production of food, including tourism. It was in this document that rural tourism first appeared as an option for development, described as an activity that "is often mentioned as having promising potential for the future of rural society" (European Commission, 1988, p. 50). Rural tourism thus emerged as a complement to agricultural and livestock activities 
(Béteille, 1996), and has been presented as a means to mitigate rural depopulation, generate additional income in rural households, and diversify the economy. Besides providing additional income for farmers, rural tourism also benefits the local population in other ways. It creates contact between urban and rural residents and offsets the main problems currently posed by rural areas such as depopulation, population aging, the loss of cultural values and traditions, and heritage deterioration. The role played by Rural Development Programs has been focused on stimulate the pull factors in rural destinations. For instance, new bed places, restaurants, facilities, new tourist products, marketing and planning activities have been developed over the past 25 years through the implementation of EU rural development policies.

These changes in the focus of European structural funds and the transition from specific projects to multi-year programs have rendered it necessary to use methodological tools to formulate coherent and effective planning processes that encompass all stages (territorial diagnosis or ex ante evaluation, definition of objectives, implementation, and subsequent or ex post evaluation). From the outset, the 1988 European Commission report The future of rural society identified the need to evaluate and monitor the programs. "These programmes must be framed on the basis of close concerted discussion with the national, regional and local authorities. Based on joint preparation, follow-up and evaluation, they must form the basis of a genuine partnership" (European Commission, 1988, p. 8). Evaluation plays a crucial role in decision-making. Not only is it a learning mechanism but it also helps tackle changes that may arise during implementation (Vidueira, DíazPuente, \& Afonso, 2013). Similarly, the planning process plays a key role in the success of a tourist destination. According to Getz (1986), the tourism planning process is based on research and evaluation, and is aimed at optimizing tourism's contribution to human well-being and environmental quality. Meanwhile, Inskeep (1988) has defined planning as organizing the future to achieve goals. Thus, the absence of planning generates impromptu growth and limits competitiveness. The existence of a high level of competition has increasingly obliged tourist destinations to differentiate themselves from their competitors, seek new solutions and offer higher quality products and services that meet consumers' needs. Tourism is a multisectoral activity encompassing a variety of sectors (infrastructure, heritage, environment, training, etc.) that exert a strong influence on the development and success of a tourism destination. It is also an activity that generates a considerable economic, cultural and environmental impact. Planning and evaluation are aimed at detecting and minimizing these drawbacks.

\section{Objectives}

The objectives of this study were: (a) to identify and examine the methodological tools proposed by the European Union for measuring the impact of rural development programs, from LEADER I to the 2007-13 Rural Development Program; (b) to identify and analyze the aspects subject to evaluation processes, paying particular attention to the methods and tools used to evaluate tourism; (c) having completed an analysis of mandatory methods, to contextualize the findings within the framework of academic research by means of a literature review; (d) to highlight possible weaknesses found in mandatory evaluation systems; and (e) to identify and discuss methodology proposals in the literature for improving evaluation systems. 


\section{Research design}

For the first part of the research (objectives a and b), we reviewed European regulations regarding evaluation of rural development policies, the assessment reports prepared by The Directorate-General for Agriculture and Rural Development, the working documents prepared by the European Network for Rural Development and the ex ante, intermediate and ex post evaluation reports on the different rural development program periods. In total, 19 documents were examined.

For the second part of the study, we conducted a literature search in the following bibliographic databases (objective c): ProQuest, Scopus, and the University of Alicante Library catalog. We used the following keywords: "rural development", "LEADER", "evaluation", and "tourism". These primary keywords were supplemented with secondary keywords that varied over the course of the different searches depending on the specific objectives in each case. Examples included "name of the region or study area" and "program period consulted", or specific aspects such as the characteristics of the LEADER approach, for instance, "innovation", "multifunctionality", "cooperation", and "bottom-up approach".

As a result of the searches conducted between February and October 2015, a total of 56 references were identified and selected for subsequent study. Given the high number of publications on rural development and tourism, and considering that a quantitative analysis of scientific production was not a priority for this study, we restricted our analysis to publications that met the following criteria. (a) scholarly papers that provided a critical analysis of mandatory evaluation systems; (b) qualitative analyses of aspects specific to the LEADER approach; (c) studies proposing new methods for evaluating rural development programs; and (d) specific analyses of the impact of rural development programs on tourism. Given the large number of publications focusing on rural development policies, we excluded descriptive studies of rural development program results in specific regions and studies which did not propose methods for evaluating rural development programs, the subject of the present research.

To achieve objectives $d$ and $e$, and by way of conclusion, we studied and compared the evaluation processes from both fields (mandatory evaluation methods versus methods proposed in the literature). An analysis and comparison of these highlighted the weaknesses of the rural development evaluation process and revealed possible future lines of research.

\section{Results and discussion}

\subsection{Systems proposed by the European Union to evaluate rural development programs in the tourism sector (1991-2015)}

European rural development policies are based on the LEADER (Liaisons entre Activités de Developpement de l'Economíe Rural) program, which was adopted in 1991 with the aim of improving the development potential of rural areas (European Commission, 2006a). In order to participate in these programs, it is necessary to reach the critical mass required to render the program viable, and to meet the rural threshold values established by the European Union. Participants form a Local Action Group (LAG), the body responsible for managing funds and designing the development strategy (Ray, 2000a). Implementation of LEADER programs is based on the injection of public funds in rural areas in order to 
revitalize activities such as local crafts, promote tourism, SMEs (small and medium enterprises), and agricultural products, and conserve and enhance the environment. To be allocated public funds, projects must comply with the seven key characteristics on which the LEADER program is based: (1) development strategies must be applied to homogeneous areas above municipal level with a local identity and sharing common problems and needs; (2) the proposed development strategy should be formulated from the bottom up, and must involve the entire community (social groups, economic interest groups, public and private associations and institutions) in all stages of the process; (3) a LAG must be constituted, which will be the body responsible for managing and allocating the financial resources received and for designing the rural development strategy; (4) projects should present a degree of innovation; (5) the strategy must integrate various sectors to promote linkages between different economic agents. It must also be multifunctional and based on the enhancement of endogenous resources; (6) the LAGs must share their experiences through network connections to create links; and (7) the LEADER approach encourages the participation of joint projects between several LAGs to mutually enrich the groups (European Commission, 2006a).

It is extremely important to be aware of the characteristics of the LEADER approach, since many of the mandatory evaluation processes revolve around analyzing and assessing the role these have played in the success of rural development programs. In theory, the LEADER approach will be one line of argument on which will revolve around the evaluation process.

\subsubsection{LEADER I (1991-94)}

The first LEADER program was launched in 1991. It was aimed at promoting development in rural areas in order to alleviate some of the typical problems these faced such as an aging population, unemployment, and the low income generated by traditional activities. The potential of rural tourism to revitalize marginal rural areas is reflected in the distribution of funding; many Member States have destined a high percentage of investment to this activity, and consider it the best sector to promote (Bull, 1999).

165 Once the first LEADER implementation period concluded in 1994, the Commission issued a call for tender to conduct an ex post evaluation study of the LEADER I Community initiative. Commission Notice 95/C 263/12 of 10 October 1995 described the LEADER I evaluation process, and also summarized the evaluation objectives (European Council, 1995). These were: (a) to evaluate the expected effects, especially on employment; (b) to evaluate the suitable use of the funds allocated; (c) to analyze the operation and efficiency of the network; (d) to determine the added value produced as a result of implementing the Community initiative. As a result, theoretically LEADER approach principles (bottom-up strategies, innovation, capacity building, integrated actions, etc.) will be evaluated. The evaluation was performed at Community level by two groups. The first of these consisted of four rural development experts from consulting firms, who were responsible for conceptualization, methodology design, project coordination and presentation of results. The second group consisted of 12 teams with members from universities and private companies mainly located in countries that had participated in LEADER I.

The evaluation of tourism-based actions was conducted using information obtained from a questionnaire administered to 50 LAGs (European Commission, 1999b). Impact 
indicators were established to evaluate the number of tourism businesses created, the volume of accommodation, and the employment generated. The LEADER I ex post evaluation presented some weaknesses, including an inadequate ex ante territorial diagnosis by the LAGs as regards the baseline situation of the region, and limited information on visitor arrivals, a crucial indicator of a destination's accommodation capacity.

\subsubsection{LEADER II (1996-99)}

The success of the first LEADER program (in terms of investment and results obtained) prompted the European Union to continue funding rural development policies. On 7 July 1994, grants for rural development were announced with the launch of the LEADER II program. In this period, the task of monitoring and evaluating rural development projects was devolved to States and regions. Accordingly, the European Commission published the document Guidelines for the ex post evaluation of the LEADER II Community Initiative (European Commission, 1994) with the aim of instructing the authorities responsible for evaluation on the procedure to follow for this task, and also to serve as a prelude to the final evaluation of LEADER II.

For tourism, new impact indicators were incorporated in addition to the indicators used previously in LEADER I. These categorized the measures implemented in the tourism sector, such as the creation of infrastructures and services, the development of routes, the implementation of booking centers, the promotion of tourism products, the enhancement of rural heritage, and the formulation of marketing plans. In addition, a guide was published on how to evaluate a territory's touristic potential (Zimmer \& Grassmann, 1996). Directed at LAGs, it indicated the essential elements to consider when formulating a strategic tourism plan, including an analysis of supply and demand and an assessment of 205 competition and consumer trends in rural tourism, as well as the key aspects of a marketing plan.

\subsubsection{LEADER Plus (2000-06)}

The third phase of the Community initiative, the LEADER Plus program (2000-06), is described in Regulation (EC) No 1260/1999 of 21 June 1999. LEADER Plus complemented earlier programs, supporting integrated activities designed and implemented by groups operating at local scale. LEADER Plus was also intended to promote the implementation of quality sustainable development strategies aimed at experimenting with new ways of enhancing natural and cultural heritage, and improving the local economy and organizational capacity of rural communities (European Council, 1999). In contrast to previous evaluation approaches, a priority objective of this program evaluation was to determine whether the adoption of actions that did not promote vertical, top-down approaches had added value to the implementation of this LEADER initiative. The European Commission issued a guide indicating the physical and financial indicators that all Member States were required monitor (European Commission, 2004). This guide was of great importance in that it contained the only general information provided to all LAGs, and would be used by all regional authorities to produce the relevant reports; therefore, it was the only documentation that would enable a comparative study between different regions. The aim of the ex post evaluation of LEADER Plus (European Commission, 2010) was to analyze the factors that had contributed to the success or failure of the projects implemented, and to examine the results. In the field of tourism, the results presented were limited to an 
in-depth analysis of the specific experiences of 10 out of the 893 LAGs that had participated throughout Europe. Nevertheless, this analysis identified good practices in various areas, such as an analysis of hotel occupancy in the German district of Roth or the introduction of innovative elements to market tourism products in the Jerte Valley (Spain). Despite these more detailed analyses, in general the quantitative information provided was inferior to that produced for LEADER I and LEADER II, since it did not include any quantitative indicators for the tourism sector at European level, or at least none were analyzed in the final LEADER Plus evaluation.

\subsubsection{Rural development program 2007-13}

As for the current 2007-13 Rural Development Program, the ex post evaluation is not scheduled for completion until December 2016. Nevertheless, many advances are envisaged in the methodology to be adopted. For instance, a guide has been issued on the procedures to follow in the 2007-13 Rural Development Program ex ante evaluation (European Commission, 2006b). An analysis of this document indicates that it will help determine the extent to which grants from the EAFRD (European Agricultural Fund for Rural Development) are consistent with the objectives of economic and social cohesion, and will facilitate optimal allocation of budgetary resources and identification of strategic priorities. This document and others included in the Common Monitoring and Evaluation Framework for Rural Development 2007-13 comprise the instruments developed by the European Commission and agreed with Member States for monitoring and evaluation of the 2007-13 Rural Development Program. In the field of tourism, priority attention has been given to the total number of new tourism projects implemented and the number of new tourist beds created, as baseline and result indicators. In contrast to the previous LEADER program, quantitative indicators for tourism once again form part of the evaluation of rural development programs. However, there is still a lack of methodological tools to measure the effectiveness and profitability of the actions implemented. Table 1 summarizes the evolution of the methods proposed for evaluating the impact of tourism.

A brief analysis of this table indicates that the specific features and intangible objectives of rural development programs render these difficult to evaluate and measure. Although LEADER approach is one of the main themes on mandatory evaluations. In reality, evaluations proposed have paid insufficient attention to the impact of LEADER approach principles. This evaluation and analysis has aroused the interest of numerous researchers, whose work will be examined in the following section.

\subsection{Scholarly contributions to the rural development program evaluation process}

Several aspects of the design, implementation, and evaluation of rural development programs have been called into question by experts and scholars over the almost 25-year history of the LEADER approach. These include the high number of public entities forming part of the LAGs, the inclusiveness of the various measures, the predominance of top-down approaches in strategy design, cooperation between LAGs, the lack of primary information, and the best methodology tools for conducting an evaluation. The 
Table 1. Evolution of indicators employed in rural development programs in the field of tourism.

LEADER+ 2000-06 Disappearance of the indicators used in LEADER I and LEADER II. Categorical step backward in quantitative data on tourism in European reports In-depth qualitative analysis of ten LAGs in the field of tourism as a case study

RDP 2007-13

The quantitative indicators absent from LEADER+ are reintroduced. The indicators used are:

\author{
Evaluation tools used in the tourism sector
}

Solely quantitative data. Interviews conducted with 50 LAGs. Criteria:

- Categorization of tourism investment according to the nature of the project

- Volume of accommodation

- Number and characteristics of jobs created in the tourism sector

LEADER II 1996-99 In addition to the quantitative indicators used in the previous period, a qualitative perspective was introduced via methodological guides related to the tourism sector that incorporated the following elements:

- Evaluation of a territory's touristic potential

- Guides for the production of specific products: promoting footpaths

- Number of new tourism actions supported

- Number of tourist beds (in hotels, campsites, holiday accommodation)

Source: By the authors.

interest aroused by the impact of rural development programs is reflected in the large number of scientific articles published and conference papers delivered on this subject.

Studies on the results of implementing LEADER programs began to emerge in the mid1990s, and have often presented similarities as regards structure and content. They have also shown a certain degree of homogeneity in the use of indicators aimed at evaluating implementation and results. Common research subjects have included studies of financial reports and the distribution of investment according to the types of measure implemented, and analyses of the contribution of each partner (public or private) and the capacity of rural development programs to mobilize private capital. These aspects have often been employed to contextualize the study, or to analyze more qualitative aspects such as the inclusiveness of the measures taken or the concept of multifunctionality. Such research has also typically included data on employment directly generated by the various projects, as well as the social, demographic, and economic characteristics of private project partners, making it possible to analyze, for example, the role of rural women in development projects (Oedl-Wieser, 2015). The main themes will be analyzed in the following subsections.

\subsubsection{Evaluation of EU rural development programs and LEADER approach}

Several of the articles studied identified weaknesses in the design, implementation and subsequent evaluation of rural development programs (e.g. Esparcia, 2014; High \& Nemes, 2007; Larrubia Vargas \& Navarro Rodríguez, 2011; Marsden \& Sonnino, 2008; Martin \& Tyler, 2006; Midmore, 1998; Ploeg et al., 2000). Some of the issues raised have included local people's limited participation in the design and subsequent evaluation of the development strategy (Panyik, Costa, \& Rátz, 2011; Ray, 2000a), the endogenous nature of program design and development (Ray, 2000b; Shucksmith, 2002), the excessive importance given to rural tourism as a socioeconomic alternative to the detriment of an inclusive and multisectoral approach (Hernández Hernández, 2009; Larrubia Vargas \& Navarro Rodríguez, 2011; Marsden \& Sonnino, 2008), the composition of the LAGs 
themselves (Macken-Walsh, 2011; Martínez Arroyo, Sacristán López, \& Yagüe Blanco, 2015; Salchner, 2013), the capacity of rural development programs to generate enterprises that are sustainable over time (Duarte Canever, Chueca Pérez, \& Pfeilstetter, 2012), the capacity of the LEADER initiative to mobilize private capital (Pérez-Fra \& Verdugo-Mates, 2005), the introduction of innovative elements in rural development program design (Esparcia, 2014), cooperation between LAGs (Chmielinski, 2011; Mcareavey \& Mcdonagh, 2010; Pollermann, Raue, \& Schnaut, 2013; Vidal, 2009), and environmental protection in rural development policies (Pepper, 1999).

The evaluation systems proposed by different public administrations have also been analyzed, revealing their weaknesses (Díez, 2002). Several authors (High \& Nemes, 2007; Larrubia Vargas \& Navarro Rodríguez, 2011; Martin \& Tyler, 2006; Midmore, 1998; Navarro Valverde, Cejudo García, \& Maroto Martos, 2012; Pana, Al Hosmi, \& Codreanu, 2013; Ploeg et al., 2000) have indicated that the mandatory rural development program evaluation systems designed by the various authorities responsible pay insufficient attention to the impact of these programs on the territory, and instead limit the analysis to an evaluation of management by LAGs. The lack has also been noted of any primary information or an adequate statistical basis for conducting a satisfactory evaluation (Vidueira, Díaz-Puente, \& Rivera, 2014). In fact, the secondary data available to researchers have largely been produced by the relevant public authorities. Given these considerations, it could be argued that much of the academic research conducted on the evaluation of rural development programs has been based on the information provided by the public authorities. Consequently, many studies have been limited to the guidelines on rural development program evaluation proposed by the European Union and discussed in the previous section.

However, several authors have suggested that besides these quantitative tools, the evaluation process should also include qualitative techniques (e.g. Midmore, 1998; Panyik et al., 2011: Viladomiu \& Rosell, 1998; Viñas, 2004). Vidueira et al. (2014) conducted an in-depth study of this question, analyzing the methodologies used by Member States to produce their ex ante evaluation reports in the period 2007-13. Among other things, their study revealed that only $40 \%$ of Member States employed qualitative techniques in their mandatory evaluations. Furthermore, it also identified some of the main obstacles to conducting evaluations, namely the difficulties entailed in calculating the importance of external factors in the evaluation process, and the heterogeneity of the diverse measures and actions taken to achieve the objectives.

350 The guidelines proposed by the European Union suggest that it is impossible to evaluate all rural development projects using the same method, a stance supported by several authors (e.g. High \& Nemes, 2007; Marangoni, 2000; Navarro Valverde et al., 2012; Seibert, 2000; Thirion, 2000; Viladomiu \& Rosell, 1998). These have argued that the design of the evaluation process depends largely on the needs and problems of the territory, its socioeconomic characteristics and the objectives to be achieved. Furthermore, it may not be feasible to adapt a common evaluation model to all rural development projects because the evaluation system must be consistent with the hierarchical level at which the evaluation is to be conducted (European, national, regional, district, or municipal). Accordingly, evaluations depend to a large extent on the previously established objectives, and these will differ according to the factors (level, perspective) that influenced methodology design (Prager, Nienaber, Neumann, \& Phillips, 2015). 


\subsubsection{Methodological proposals for evaluating rural development programs}

Due to the continuing debate and difficulties surrounding the development of an evaluation model capable of addressing the specific features of LEADER projects, many authors have proposed new techniques and even new methods for their evaluation. For instance, Viñas (2004) has suggested that interviews with local informants and local people, focus groups, and participant observation would be the most suitable types of qualitative technique for evaluating rural development projects. She also analyzed the potential advantages and disadvantages of using the different tools proposed. Along the same lines, Midmore (1998) has examined the techniques and tools selected to evaluate rural development projects.

Other authors have suggested the need to develop new evaluation methods. For example, Marangoni (2000) designed a participatory self-evaluation method for subsequent use with LAGs from the Italian region of Emilia-Romagna, which focused mainly on examining a bottom-up approach to strategy design. Thirion (2000) has also proposed a new method for evaluating rural development projects, based on systemized participatory self-evaluation. This combines an evaluation of the territory's evolution, an analysis of the implementation of the LEADER approach, and an assessment of operational change in the LAGs. The method also takes into account all the intangible elements (expert knowledge, social cohesion, types of governance, relationships between agents, culture, and identity) that are sometimes underrated but actually represent added value in the development of rural areas. In the first phase of this method, a global and subjective evaluation of the territory is performed using a Likert scale to assign a score for the evolution of several aspects of the territory over the past decade, including quality of life, heritage and natural resources, demography, identity and image, expert and technological knowledge, internal relations, cohesion, and demographics, diversification and integration of economic activities, and external relations. In the second phase, the above aspects are re-evaluated, but this time taking into account the actions implemented by the LAGs within the framework of the LEADER program.

Another method called bottleneck analysis has been developed by Seibert (2000), who proposed a participatory evaluation system in relation to the definition of objectives. He noted that to a large extent, the success or failure of a territory depends on soft factors (key factors that have a considerable impact on development), and that successful development therefore depends on directing efforts toward these strategic areas. To accurately determine the key factors or areas (soft factors) that generated a bottleneck effect, indepth interviews were held with representatives of 30 LAGs in Bavaria (Germany) and Luxembourg. The key areas identified corresponded largely to several elements intrinsic to the LEADER initiative, namely: revitalization of regional living conditions, the creation new economic activities and rural dynamics, the joint acquisition of expertise (transfer of know-how, innovation, and cooperation), appropriate structures and cooperation between LAGs, development based on regional identity and culture, attractiveness of the region (image), and social and economic attractiveness (an attractive environment in which to live and work).

The study by De Los Ríos-Carmenado, Turek Rahoveanu, Salvo, and Rodríguez (2012) was based on similar principles, using a planning model called "Working with People" to identify the key strategic factors limiting rural development in Romania. Through 
focus groups with rural development experts, they established that the main limiting factors were a shortage of skilled human capital, difficulties in attracting funding, lack of technology, high taxes, and, to a lesser extent, low agricultural productivity, a scant tradition of cooperation, and limited promotion of local products.

In another study, Prager et al. (2015) examined some aspects of the design and implementation of rural development project evaluation systems and identified a number of problematic issues. They found that many policies and lines of action had poorly defined and contradictory objectives, that there were difficulties in clearly defining the expected results of implementing this initiative, that measures overlapped due to their integrated, multisectoral approach, rendering it difficult to attribute causation and subsequent effect on a territory to any given measure, that there was still a need to determine the best time to conduct an evaluation, and that LAG managers rejected the idea of participating in self-evaluation processes that might reveal discrepancies in achieving objectives.

These considerations, and in particular those pertaining to multisectoral approaches, have also been discussed by Papadopoulou, Hasanagas, and Harvey (2010) in their study on the implementation of LEADER in Greece. They suggested that project results emerge from interactions between the various measures implemented; consequently, they cannot be directly related to or associated with individual actions. To analyze the impacts associated with implementation of this program, they employed network theory, which focuses on interactions between local actors. Private investors promoting LEADER-funded projects were interviewed to analyze their opinions on the bureaucratic burden involved in obtaining grants, the clarity of policy content, the investor's hierarchical position in the pyramid of power, and the achievement of objectives.

\subsubsection{Tourism and rural development program evaluations}

Given the aspects analyzed in the methodological proposals described above, and despite the importance of tourism in rural development projects, especially in the initial programs, it is clear that few studies have assessed the impact of rural tourism actions in areas where rural development projects have been implemented. Although LEADER is the largest rural tourism promotion program in Europe (Panyik et al., 2011; Salchner, 2013), there is very little research in the literature on the evaluation of tourism measures. "One of the weaknesses is the lack of studies demonstrating the contributions that rural tourism generates in a territory through rural development grants" (Larrubia Vargas \& Navarro Rodríguez, 2011, p. 63).

This aspect is difficult to evaluate given the specific features of rural development projects and the multisectoral nature of tourism. Thus, much research has been based on the data produced by the relevant authorities and the reports submitted by the LAGs. In particular, these studies have analyzed tourism projects according to their financial reports, although some have also examined more specific aspects of the impact of rural development programs on tourism.

Beltrán Fernández (2014) has analyzed the role played by promotion as a tourism development strategy in rural Spanish regions implementing LEADER projects. In another study, Salchner (2013) explored whether the LEADER approach had contributed to the launch of innovative projects in the tourism sector. Along the same lines, Reinoso Moreno and Sancho Comíns (2009) studied nine Spanish LAGs from the perspective of tourism. 
Table 2. Research related to rural development program evaluation.

455

\section{Contributions to the} evaluation process
Cooperation, networking, and innovation

Multifunctionality and inclusiveness

Endogenous nature

Descriptive studies and Analysis of the distribution of investment by measures, funding analyses public-private investment, and spatial distribution

Descriptive analyses of Community regulations concerning rural development grants

Capacity of the LEADER initiative to generate companies and entrepreneurship and to mobilize capital and employment

Analysis of methodological tools to evaluate rural development programs

Methodological proposals
Analysis of weaknesses in mandatory evaluation systems
Díez (2002)

Navarro et al. (2012)

Viladomiu and Rosell (1998)

Prager et al. (2015) Vidueira et al. (2014)

Viñas (2004)

Midmore (1998)

Bachtler and Wren (2006)

Seibert (2000)

Marangoni (2000)

Thirion (2000)
Area/region studied

Romania

Austria

Republic of Ireland

AQ13

Poland

European Union

European Union

Germany

Valencia and

Murcia (Spain)

European Union

Greece

UK

European Union

UK

European Union

European Union

European Union Pagliacci, and

Sotte (2013)

European Union

European Union

Spain

Italy, Spain and France

France, Spain and Germany

Galicia (Spain)

\section{AQ15}

\section{AQ16}

European Union

European Union

European Union

European Union

European Union

European Union

European Union

European Union

European Union

Bavaria (Germany)

GAL Emilia-Romaña (Italy)

Portugal 
Table 2. Continued.

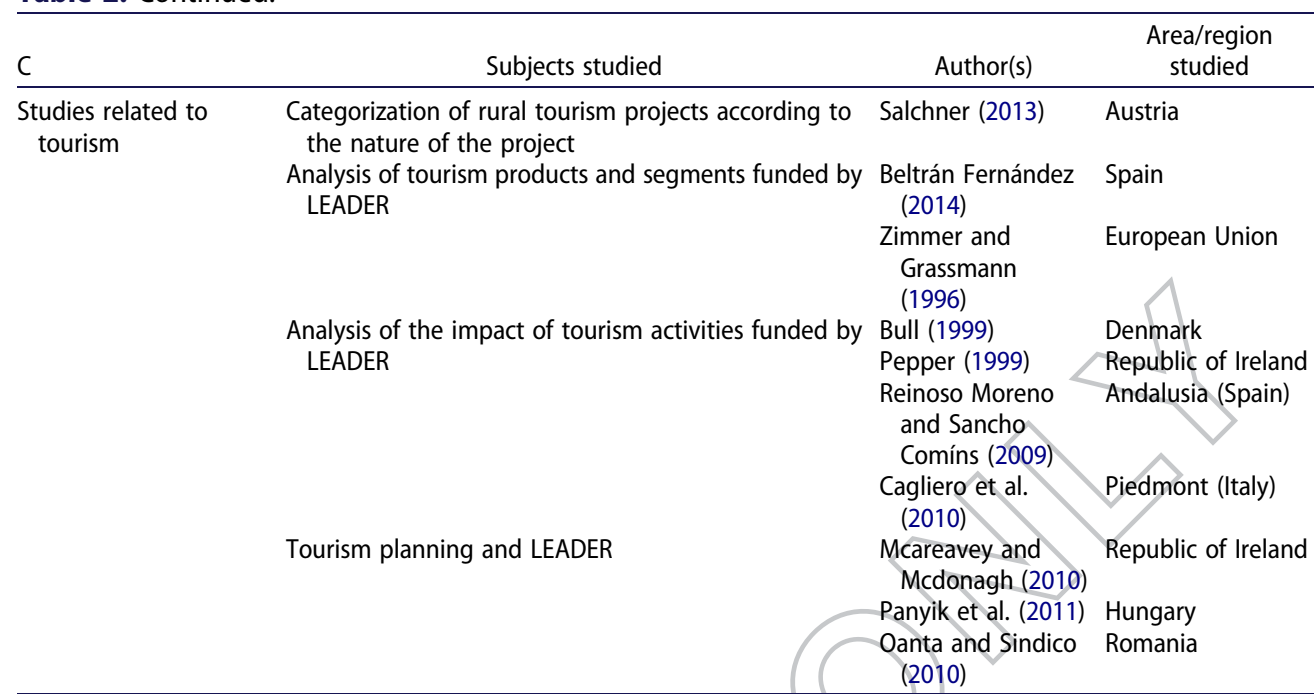

Source: By the authors.

Note: C: Category.

Besides analyzing the financial reports for the tourism measures implemented, they also examined other aspects such as the sociodemographic profile of the partners and the employment generated, conducting surveys and holding in-depth interviews about actions in the field of tourism with mayors, private partners, representatives of associations, and LAG experts. In their study, Cagliero, Filippa, and Pierangeli (2010) incorporated additional indicators to measure the impact of tourism, such as the accessibility of regions, the existence of complementary services and the creation of tourist routes.

The papers analyzed in this section are compiled and categorized in Table 2.

\section{Conclusions}

In light of the above, our review of the literature on rural development program evaluation and analysis of the evolution of Community guidelines on evaluation demonstrate that gaps continue to exist as regards evaluating the impact of the LEADER initiative, and these require research attention.

(a) We did not find any studies on the geographical origin of private investors, a question of considerable importance for several reasons. Firstly, priority should be given to promoting investment by local people, since these both live with the problems that arise in rural areas and are the target population for whom the grants are intended. Furthermore, local investment may lead to a multiplier effect and possible reinvestment within the territory of profits generated. In contrast, foreign investors attracted to rural areas by the promise of European Community funds may not have this same impact on the local economy. Secondly, foreign investors in the field of tourism could distort territorial identity and diminish the unique worth of local resources. Although the capacity to mobilize private capital is considered an indicator of success and has been analyzed in previous studies, further research on this aspect is required. 
(b) A second question is the definition of objectives, a key aspect in the LEADER initiative. Besides being measurable and achievable, these must be clearly and concisely specified. The process of defining and establishing objectives will determine subsequent stages of the planning process, and they should be consistent with the method of analysis employed. The aims and/or objectives proposed by the European Union could be classified as the mission or rationale of rural development programs. In addition, this lack of precision in the definition of objectives is also reflected in the lower levels of management (national, regional, and local), which in turn affects the evaluation of results.

(c) A third aspect our study has revealed is the need to consider the role of local people. Attempts to involve local people in the evaluation process will be fruitless if they have not previously been included in the other stages of the planning process. Many studies have discussed participatory evaluation; however, this is sometimes restricted to people directly related to rural development projects (e.g. project investors, LAG experts and managers, representatives of associations, and mayors), and does not take the opinion of the local 555 populace into account. Apart from that, stakeholders related to tourism sector could take part in participatory processes.

(d) Another aspect demonstrated by an analysis of the European documents concerning evaluation of these initiatives is the slowness and delay in performing evaluations, hindering the feedback process. Time-consuming administrative paperwork, bureaucracy, and the frequent failure to use ICTs in evaluation procedures combine to protract the process and hamper the continuity and monitoring that should be a feature of any planning process. The lack of statistical data on tourism available for ex ante evaluations also impedes the use of quasi-experimental statistical methods with measures to be applied before and after this initial eyaluation.

565 (e) To date, most studies have proposed global working methods for evaluating rural development programs, viewing tourism, local crafts, training, or the promotion and marketing of agricultural products as actions capable of alleviating the problems that arise in rural areas. However, these activities are always regarded simply as a means to achieve European structural objectives and have rarely been considered as independent strategic processes. In tourism, this lack of planning in rural development programs is reflected in general terms in the oversupply of rural accommodation that has been created over the nearly 25 years of allocating LEADER funds, distortions in tourist image, low ICT use, weakness in marketing activities. An ex ante evaluation focus on tourism analysis will enhance the efficiency of tourism projects and will help to get synergies in rural destinations.

(f) There is no question that the implementation of tourism actions in LEADER territories has contributed to improving the quality of life in rural areas. Tourism has generated employment in the past and continues to do so. Furthermore, it contributes to the promotion of local products, helps prevent the loss of cultural values and traditions, fosters the restoration and interpretation of historic and artistic heritage, and has prompted improvements to infrastructures and transportation networks. Nevertheless, approaches to evaluation in the field of tourism have focused solely on figures, usually financial and impact indicators (number of tourism-related jobs and tourist beds created). Although these do indeed measure the actions implemented in the field of tourism, they do not take the results into account, and more specifically, they do not quantify the effectiveness, efficiency, and profitability of investment. Additionally, all these impacts should not be attributed to the EU Rural Development Programs. This is due to the fact that there are 
more factors than Rural Development Funds, namely, LAG-interventions, network connections, innovation, capacity building.

In tourism, these aspects are measured by indicators related to demand, such as the number of tourist arrivals, their sociodemographic characteristics, hotel occupancy, and average spending per tourist. Without them, it difficult to use experimental methods to analyze causation. The failure to use these indicators cannot be justified on the grounds that to do so would entail unacceptably high costs, since LAGs participating in rural development programs receive funding to carry out such studies. Furthermore, these indicators were in fact included in the evaluation guidelines issued by the European Union. In any case, mandatory evaluation system need to be questioned, most of the analyzed studies face the research from a holistic perspective. It would be of benefit to discuss in depth the operability of tourist projects.

(g) Similarly, few studies have addressed the intrinsic characteristics of the LEADER approach from a sectoral perspective. There is a distinct lack of research analyzing issues such as the influence of tourism on the partnership structure of LAGs, how innovation is incorporated into tourism projects, the synergies that have been generated in tourism projects implemented jointly by different LAGs working in cooperation, the role tourism plays in local identity processes, or the interrelationships and synergies that arise from the inclusive and multifunctional nature of the actions implemented. These synergies and advantages sometimes pass unnoticed in the tourism sector due to their multisectoral nature and because they form part of other intervention areas such as heritage restoration, or the promotion of local crafts or food products - all actions which in turn are nourished by tourism.

In light of the results obtained from an analysis of the evaluation methods proposed by the European Union and in the literature, future evaluation processes should consider external factors that encourage the influx of tourists, such as the existence of attractive 610 and differentiated tourism products, proximity in time and cost to source markets, the presence of competitive complementary services, or the stage reached by the tourism destination. Along the same lines, it is also necessary to study the impact on these areas of changing tastes among consumers seeking rural tourist destinations. These demand destinations that offer life experiences, and this entails socializing with the local population; they 615 therefore seek products that enable them to participate in traditional activities and learn about local history and culture. This type of experiential tourism is even more satisfying if the surrounding environment preserves the authenticity of the past. Rurality and isolation from the urban world are qualities that represent a comparative advantage for tourist destinations; however, the use of European funds for rural development could undermine these assets. Thus, rural development programs aimed at reducing disparities between urban and rural areas could limit the competitiveness of these latter regions as tourist destinations.

\section{Disclosure statement}

625 No potential conflict of interest was reported by the authors.

\section{Funding information}

This research was supported by the Office of the Vice President for Research, Development and Innovation of Universidad de Alicante [UAFPU2014-5887] and Ministerio de Economía y Competitividad 


\section{ORCID}

Juan Gabriel Tirado Ballesteros (D) http://orcid.org/0000-0002-1216-4673

María Hernández Hernández (1) http://orcid.org/0000-0002-8823-0083

\section{References}

Bachtler, J., \& Wren, C. (2006). Evaluation of European Union cohesion policy: Research questions and policy challenges. Regional Studies, 40(2), 143-153. doi:10.1080/00343400600600454

Beltrán Fernández, C. (2014). La experiencia española en la promoción turística a través de la UE: el programa Leader [The Spanish experience in promoting tourism through the EU Leader program]. Papers de Turisme, 17, 25-31. Retrieved from http://www.papersdeturisme.gva.es/ojs/index.php/ Papers/article/view/292

Berkel van, D. B., \& Verburg, P. H. (2011). Sensitising rural policy: Assessing spatial variation in rural development options for Europe. Land Use Policy, 28(3), 447-459. doi:10.1016/j.landusepol.2010. 09.002

Béteille, R. (1996). L'agritourisme dans les espaces ruraux européens [Farmhouse in European rural areas]. Annales de Géographie, 5. Retrieved from http://www.jstor.org/stable/23454823

Bull, B. (1999). Encouraging tourism development through the EU structural funds: A case study of the implementation of EU programmes on Bornholm. The International Journal of Tourism Research, 1(3), 149. doi:10.1002/(SICI)1522-1970(199905/06)1:3<149::AID-JTR167>3.0.CO;2-S

Cagliero, R., Filippa, F., \& Pierangeli, F. (2010, August). RDP and Quality of Life in rural areas: Evaluation of the possible effects in Piedmont. Paper presented in 118th seminar of the EAAE (European Association of Agricultural Economists), Rural development: Governance, policy design and delivery, Ljubljana, Slovenia. Retrieved from http://ageconsearch.umn.edu/bitstream/94912/2/ Cagliero-RDP_and_quality_of_life_in_rural_areas-209.pdf

Camaioni, B., Esposti, R., Lobianco, A., Pagliacci, F., \& Sotte, F. (2013). How rural is the EU RDP? An analysis through spatial fund allocation. Bio-based and Applied Economics, 2(3), 277-300. doi:10. 13128/BAE-13092

Chmielinski, P. (2011). On community involvement in rural development - a case of leader programme in Poland. Economics \& Sociology, 4(2), 120-128. doi:10.14254/2071-789X.2011/4-2/11

De Los Ríos-Carmenado, I., Turek Rahoveanu, A., Salvo, M., \& Rodríguez, P. (2012, October). Territorial competitiveness for rural development in Romania: Analysis of critical influential factors from WWP model. Paper presented in 3rd International Symposium "Agrarian Economy and Rural Development - Realities and Perspectives for Romania" (AERD 12), Bucharest, Romania. Retrieved from http://www.cabdirect.org/abstracts/20133042307.html;jsessionid=2EE9A12A6 C92CEC3E5AB0565417AC897

Díez, M. A. (2002). Evaluating new regional policies reviewing the theory and practice. Evaluation, 8 (3), 285-305. doi:10.1177/135638902401462439

Duarte Canever, M., Chueca Pérez, A., \& Pfeilstetter, R. (2012). An evaluation of entrepreneurship orientation within the LEADER+ program in the European Union. Investigaciones Regionales, 22, 155-164. Retrieved from http://www.aecr.org/images/ImatgesArticles/2012/5/07_DUARTE.pdf

Esparcia, J. (2014). Innovation and networks in rural areas. An analysis from European innovative projects. Journal of Rural Studies, 34, 1-14. doi:10.1016/j.jrurstud.2013.12.004

European Commission. (1988). The future of rural society. Commission communication transmitted to the Council and to the European Parliament on 29 July 1988. COM (88) 501. Retrieved from http:// ec.europa.eu/agriculture/cap-history/crisis-years-1980s/com88-501_en.pdf

European Commission. (1994). Guidelines for the ex post evaluation of the LEADER II Community Initiative. Directorate-General for Agriculture and Rural Development. Brussels. Retrieved from http://ec.europa.eu/agriculture/eval/leaderen.pdf

European Commission. (1999a). European spatial development perspective (ESDP). Published by the European Commission, Luxembourg, Towards a balanced and sustainable development of the Union territory. 
European Commission. (1999b, March). Ex-post evaluation of the Leader I community initiative 19891993 (Final Report). Retrieved from http://ec.europa.eu/agriculture/rur/leader1/index_en.htm

European Commission. (2004). Common indicators for monitoring rural development programming 2000-2006 (Commission Working Document D/761 FINAL: 01.2005). Directorate-General for Agriculture and Rural Development. Brussels. Retrieved from http://ec.europa.eu/agriculture/rur/ eval/guide_en.pdf

European Commission. (2006a). The leader approach: A basic guide. Retrieved from http://ec.europa. eu/agriculture/publi/fact/leader/2006_en.pdf

European Commission. (2006b). Guidance note C - ex-ante evaluation guidelines including SEA. Handbook on Common Monitoring and Evaluation Framework. Directorate-General for Agriculture and Rural Development. Brussels. Retrieved from http://ec.europa.eu/agriculture/ rurdev/eval/guidance/note_c_en.pdf

European Commission. (2010). Ex-post evaluation of LEADER submitted by Metis GmbH with AEIDL and CEU as subcontractors. Vienna, Austria. Retrieved from http://ec.europa.eu/agriculture/eval/ reports/leaderplus-expost/fulltext_en.pdf

European Council. (1995). Notice by the Commission 95/C 263/12 of 10 October 1995 about ex-post evaluation study of the Community LEADER Initiative. Retrieved from http://eur-lex.europa.eu/ legal-content/EN/TXT/PDF/?uri=OJ:C:1995:263:FULL\&from=ES

European Council. (1999, June 26). Regulation (CE) No 1260/1999 of 21 June 1999 laying down general provisions on the Structural Funds. Official Journal of the European Union. L 161/1. Retrieved from http://ec.europa.eu/regional_policy/sources/docoffic/official/regulation/content/ en/02_pdf/00_1_sf_1_en.pdf

695 Getz, D. (1986). Models in tourism planning: Towards integration of theory and practice. Tourism Management, 7(1), 21-32. doi:10.1016/0261-5177(86)90054-3

Greer, A. (2013). The Common Agricultural Policy and the EU budget: Stasis or change? European Journal of Government and Economics, 2(2), 119-136. Retrieved from http://www.ejge.org/index. php/ejge/article/view/47

Hernández Hernández, M. (2009). The multifunctionality of rural environments: Between utopia and reality. The example of the Autonomous Region of Valencia and Murcia. In $\mathrm{M}^{\mathrm{a}} \mathrm{L}$. Frutos, E. Climent, \& E. Ruiz (Eds.), New ruralities and sustainable use of territory. XVI Annual Conference of Commison of the sustainability of Rural Systems (pp. 333-348). Zaragoza: Prensas Universitarias de Zaragoza.

High, C., \& Nemes, G. (2007). Social learning in LEADER: Exogenous, endogenous and hybrid evaluation in rural development. Sociologia Ruralis, 47(2), 103-119. doi:10.1111/j.1467-9523.2007.00430.x

Inskeep, E. (1988). Tourism planning: An emerging specialization. Journal of the American Planning Association, 54(3), 360-372. doi:10.1080/01944368808976497

Larrubia Vargas, R., \& Navarro Rodríguez, S. R. (2011). El desarrollo rural a través de las aportaciones científicas-académicas en revistas españolas (1990-2010) [The rural development through the scientific-academic contributions in Spanish journals (1990-2010)]. Anales de Geografía de la Universidad Complutense, 31(1), 61-81. doi:10.5209/rev_AGUC.2011.v31.n1.3

Macken-Walsh, A. (2011). Partnership and subsidiarity? A case-study of farmers' participation in contemporary EU governance and rural development initiatives. Rural Society, 21(1), 43-53. doi:10. 5172/rsj.2011.21.1.43

Mantino, F. (2013). What is going to change in EU rural development policies after 2013? Main implications in different national contexts. Bio-based and Applied Economics, 2(2), 191-207. doi:10. 13128/BAE-12989

Marangoni, S. (2000). Methodology for evaluating the LEADER specific features as applied to the EmiliaRomagna LAG. Seminar: Improving the quality of the LEADER II assessments. The LEADER II European Observatory. Brussels. Retrieved from http://ec.europa.eu/agriculture/rur/leader2/ forum/docs_evaluation/marangoni_en.pdf

Marsden, T., \& Sonnino, R. (2008). Rural development and the regional state: Denying multifunctional agriculture in the UK. Journal of Rural Studies, 24(4), 422-431. doi:10.1016/j.jrurstud.2008.04.001

Martin, R., \& Tyler, P. (2006). Evaluating the impact of the structural funds on objective 1 regions: An exploratory discussion. Regional Studies, 40(2), 201-210. doi:10.1080/00343400600600546 
Martínez Arroyo, F., Sacristán López, H., \& Yagüe Blanco, J. L. (2015). Are local action groups, under LEADER approach, a good way to support resilience in rural areas? Ager: Journal of Depopulation and Rural Development Studies, 18, 39-63. doi:10.4422/ager.2015.06

Mcareavey, R., \& Mcdonagh, J. (2010). Sustainable rural tourism: Lessons for rural development. Sociologia Ruralis, 51(2), 175-194. doi:10.1111/j.1467-9523.2010.00529.x

Midmore, P. (1998). Rural policy reform and local development programmes: Appropriate evaluation procedures. Journal of Agricultural Economics, 49(3), 409-426. doi:10.1111/j.1477-9552.1998. tb01281.x

Navarro Valverde, F. A., Cejudo García, E., \& Maroto Martos, J. C. (2012). Contributions to the evaluation of rural development programmes. Boletín de la Asociación de Geógrafos Españoles, 58, 349-379. Retrieved from http://boletin.age-geografia.es/articulos/58/32-NAVARRO.pdf

Oanta, G., \& Sindico, F. (2010). The Lisbon Treaty and its consequences for rural development and sustainable tourism: A case study of Romania. Yearbook of the "Gh. Zane" Institute of Economic Researches, 19, 27-42. Retrieved from http://works.bepress.com/fsindico/5/

Oedl-Wieser, T. (2015). Gender equality: A core dimension in rural development programmes in Austria? Gender, Place and Culture, 22(5), 685-699. doi:10.1080/0966369X.2013.879103

Pana, D. I., Al Hosmi, S., \& Codreanu, S. (2013). The information management within the evaluation process of the projects financed by the European Agricutural Fund for Rural Development. Valahian Journal of Economic Studies, 4(4), 53. Retrieved from http://www.vjes.eu/index.php/ archive/91-2013/115.html

Panyik, E., Costa, C., \& Rátz, T. (2011). Implementing integrated rural tourism: An event-based approach. Tourism Management, 32(6), 1352-1363. doi:10.1016/j.tourman.2011.01.009

Papadopoulou, E., Hasanagas, N., \& Harvey, D. (2010). Analysis of rural development policy networks in Greece: Is LEADER really different? Land Use Policy, 28(4), 663-673. doi:10.1016/j.landusepol. 2010.11.005

Pepper, D. (1999). The integration of environmental sustainability considerations into EU development policy: A case study of the LEADER initiative in the West of Ireland. Journal of Environmental Planning and Management, 42(2), 167-187. doi:10.1080/09640569911208

Pérez-Fra, M. M., \& Verdugo-Mates, R. (2005). Is the LEADER initiative a real contribution to rural development in underdevelopment areas in Europe? Journal of Social Sciences, 1(1), 52-56. doi:10.3844/ jssp.2005.52.56

Ploeg, J. D. van der, Renting, H., Brunori, G., Knichel, K., Mannion, J., Marsden, T., De Roest, K., ... Ventura, F. (2000). Rural development: From practices and policies towards theory. Sociologia Ruralis, 40(4), 391-408. doi:10.1111/1467-9523.00156

Pollermann, K., Raue, P., \& Schnaut, G. (2013). Rural development experiences in Germany: Opportunities and obstacles in fostering smart places through LEADER. Studies in Agricultural Economics, 115(2), 111-117. doi:10.7896/j.1228

Prager, K., Nienaber, B., Neumann, B., \& Phillips, A. (2015). How should rural policy be evaluated if it aims to foster community involvement in environmental management? Journal of Rural Studies, 37, 120-131. doi:10.1016/j.jrurstud.2014.12.006

755 Ray, C. (2000a). The EU LEADER programme: Rural development laboratory. Sociologia Ruralis, 40, 163-171. doi:10.1111/1467-9523.00138

Ray, C. (2000b). Endogenous socio-economic development in the European union-issues of evaluation. Journal of Rural Studies, 16, 447-458. doi:10.1016/S0743-0167(00)00012-7

Reinoso Moreno, D., \& Sancho Comíns, J. (2009). Quantitative impact and qualitative evaluation of rural tourism in inner Spain regions: An outcome from evaluation of the LEADER and PRODER programs. In Ma. L. Frutos, E. Climent, \& E. Ruiz (Eds.), New ruralities and sustainable use of territory. XVI annual conference of commission of the sustainability of rural systems (pp. 495-508). Zaragoza: Prensas Universitarias de Zaragoza.

Salchner, G. (2013, May). Does the LEADER method produce innovation in rural tourism development? Paper presented in New challenges of economic and business development, Riga, University of Latvia. Retrieved from http://www.evf.lu.lv/fileadmin/user_upload/lu_portal/projekti/evf/ konferences/konference_2013/report/7Session/Salchner.pdf 
Salmon, K. (2008). New directions in European reginal policy and their implications for Spain. Investigaciones regionales, (12), 147-177. Retrieved from http://www.aecr.org/images/ ImatgesArticles/2008/07b\%20Salmon.pdf

Seibert, O. (2000). Bottleneck analysis - a method for evaluating and assessing qualitative characteristics in the rural development process. Seminar: Improving the quality of the LEADER II assessments. The LEADER II European Observatory. Brussels. Retrieved from http://ec.europa.eu/agriculture/rur/ leader2/forum/docs_evaluation/seibert_en.pdf

Shucksmith, M. (2002). Endogenous development, social capital and social inclusion: Perpectives from LEADER in the UK. Sociologia Ruralis, 40(2), 208-218. doi:10.1111/1467-9523.00143

Thirion, S. (2000). The SPSA method in Portugal (Systematisation of Participatory Self-Assessment). Seminar: Improving the quality of the LEADER II assessments. The LEADER II European Observatory. Brussels. Retrieved from http://ec.europa.eu/agriculture/rur/leader2/forum/docs evaluation/thirion_en.pdf

Vidal, R. V. V. (2009). Rural development within the EU LEADER+ programme: New tools and technologies. Al \& Society, 23(4), 575-602. doi:10.1007/s00146-007-0178-2

Vidueira, P., Díaz-Puente, J. M., \& Afonso, A. (2013). The worldwide expansion of evaluation: A world of possibilities for rural development. Cuadernos de Desarrollo Rural, 10(70), 159-180. Retrieved from http://www.scielo.org.co/scielo.php?script=sci_arttext\&pid=S0122-14502013000100008

Vidueira, P., Díaz-Puente, J. M., \& Rivera, M. (2014). Socioeconomic impact assessment in ex ante evaluations: A case study on the rural development programs of the European Union. Evaluation Review, 38(4), 309-335. doi:10.1177/0193841X14552357

Viladomiu, L., \& Rosell, J. (1998). Evaluando políticas, programas y actuaciones de desarrollo rural [Evaluating policies, programs and activities of rural development]. Economía agraria, 182, 297308. Retrieved from http://dialnet.unirioja.es/servlet/articulo?codigo $=721710$

Viñas, V. (2004). Evaluación cualitativa de programas de desarrollo regional en zonas rurales [Qualitative evaluation of regional development programmes in rural areas]. Revista de estudios regionales, 71, 13-36. Retrieved from: http://dialnet.unirioja.es/servlet/articulo?codigo=1069126

Zimmer, P., \& Grassmann, S. (1996). Evaluating a territory's touristic potential. AEIDL. Brussels: European Commission. Retrieved from http://superdoc.aeidl.eu/documents/PUBLICATIONS_ AEIDL/LEADER_tourisme-EN.pdf 